\title{
STEM による材料界面の原子レベル観察
}

\author{
柴田 直哉 ${ }^{1,2}$ ・幾原 雄一 ${ }^{1,3}$ \\ 1東京大学大学院工学系研究科総合研究機構 恶 113-8656 東京都文京区弥生 2-11-16 \\ 2科学技術振興機構さきがけ研究員 凿 332-0012 埼玉県川口市本町 4-1-8 \\ 3ファインセラミックスセンター・ナノ構造研究所 矛 456-8587 愛知県名古屋市熱田区六野 2-4-1
}

（2013 年 2 月 10 日受付；2013 年 3 月 14 日掲載決定）

\section{Atomic-Scale Interface Characterization by STEM}

Naoya Shibata, ${ }^{1,2}$ and Yuichi IKUhara ${ }^{1,3}$

${ }^{1}$ Institute of Engineering Innovation, The University of Tokyo, 2-11-16 Yayoi, Bunkyo-ku, Tokyo 113-8656

${ }^{2}$ Japan Science and Technology Agency, PRESTO, 4-1-8 Honcho, Kawaguchi, Saitama 332-0012

${ }^{3}$ Nanostructures Research Laboratory, Japan Fine Ceramics Center, 2-4-1 Mutsuno, Atsuta-ku, Nagoya, Aichi 456-8587

(Received February 10, 2013 ; Accepted March 14, 2013)

\begin{abstract}
Aberration-corrected scanning transmission electron microscopy (STEM) is becoming a very powerful tool to directly characterize defect structures in materials and devices at atomic dimensions. Here, we review our recent researches on material interface characterization using STEM. First example is that the direct imaging of individual dopant atoms within a buried alumina interface. The second example is the atomic-scale characterization of Au nanoislands on $\mathrm{TiO}_{2}$ substrates. The ability to directly probe individual atoms within buried interfaces at very high-resolution will significantly assists our understanding of interface structures and related properties in many advanced materials and devices.
\end{abstract}

KEYWORDS : STEM, interface, dopant, surface

\section{1.は じめに}

走查型透過電子顕微鏡法 (STEM) は, (1)高空間分解 能, (2)優れた原子直視性, (3)構成元素の原子番号 (Z) を反映した像コントラスト, (4)他の分析手法との高い適 合性, などの優れた特徵を有し, 結晶構造が局所的に乱 れた格子不整合領域の解析にきわめて有利である。中で も, 高角散乱された電子のみを用いて結像する高角度環 状暗視野 (HAADF) 法は, 粒界 - 界面の異種原子位置 を単原子カラムレベルで検出することを可能にし，材料 の界面機能, ドーパント効果の本質的解明に向けた研究 分野に大きく貢献している。

近年の収差補正技術に代表される電子光学系の発展 は, STEM 法のポテンシャルをさらに押し広げ, 界面構 造解析に新たな展開をもたらしている。本稿では,

E-mail : shibata@sigma.t.u-tokyo.ac.jp
STEM 法のさらなる可能性を開く応用研究例として, 埋 もれた界面中の不純物原子 1 個の可視化技術 ${ }^{1)}$ および金 微粒子 $/ \mathrm{TiO}_{2}$ 界面原子構造解析 ${ }^{2}$ を紹介する。特に, 通 常の断面 STEM 観察とは異なる平面 STEM 観察におい て，有益な情報が得られる可能性を提案する。

\section{2. 埋もれた界面に偏析した原子 1 個 1 個の直 接観察}

材料内部に存在する微細界面構造は, 材料特性を決定 付ける重要な構造的因子である。近年, このような材料 界面を原子レベルで積極的に利用した新材料・デバイス 開発が進展している。界面を原子レベルで制御する手法 の一つに異種元素をドープする界面ドーピングがあ

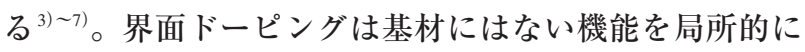
付加することができるため, 積層膜の界面や多結晶体の 粒界など様々な界面に応用可能なコンセプトであり，今 後材料を制御する上での重要な指針になると考えられ 
る。しかし，界面上のドーパント原子がどのような構造 を形成するのか, あるいはそもそもどのようなドーパン 卜原子が界面に入りうるのかに関する明確な指針は存在 せず，実験的にも材料内部に埋まった界面上のドーパン 卜原子構造を 3 次元的に決定することはきわめて困難で ある。そこで, 本節では収差補正 STEM を用いること により，材料界面原子 1 個 1 個を直接観察する手法につ いて紹介する ${ }^{1), 8}$ 。本手法は界面垂直方向から電子線を 入射する平面 (plan-view) 観察により, 界面上に存在す るドーパント原子 1 個 1 個を可視化する手法である。以 下にその詳細を順を追って示す。

\section{1 アルミナモデル粒界の作製}

本研究ではアルミナ $\left(\alpha-\mathrm{Al}_{2} \mathrm{O}_{3}\right)$ 粒界をモデル界面と して研究を行った。 $\mathrm{Al}_{2} \mathrm{O}_{3}$ セラミックスは代表的な構造 用セラミックスであり, 微量の希土類元素をドープする ことにより高温クリープ強度を著しく向上できることが 知られている。これらの希土類元素は結晶粒界に偏析 し, 界面の構造㧍よび電子状態を劇的に変化させること により, 界面強度を向上させると考えられている6)。本 研究では, 二つの制御された単結晶を高温接合すること により人工的に粒界を作製した。ドーパント元素として Y を選択し, 高温接合前にアセテート溶液として接合面 に塗布することで粒界に添加した。今回作製した結晶粒 界の結晶方位関係を Fig. 1 に示す。対応格子理論からこ の粒界は $\Sigma 13$ の方位関係にある。また粒界面は $\{10 \overline{1} 4\}$

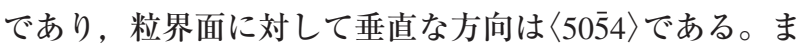
た粒界面と平行な二つの直行する方向として，〈12 10$\rangle$ 扔 よび〈2021〉が存在する。この粒界を HAADF STEMによ り互いに直交する〈1210 10 抢よび〈2021〉方向から断面観察 した結果を Fig. 2 に示す ${ }^{1)}$ 。結晶内部の明るいコントラ ストは $\mathrm{Al}$ を含む原子カラムに対応しており，粒界には

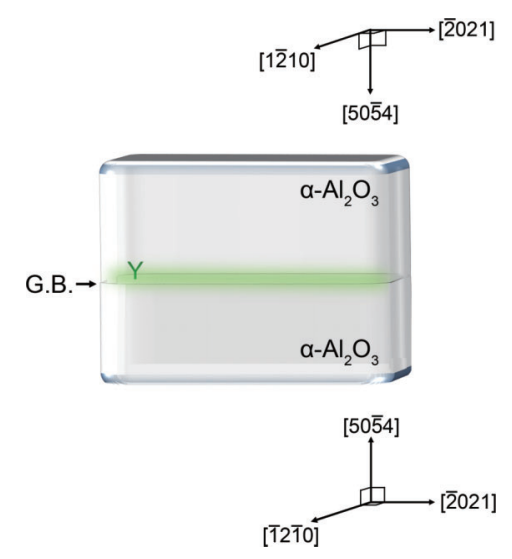

Fig. 1. (color online). Schematic illustration of the $\alpha-\mathrm{Al}_{2} \mathrm{O}_{3}$ bicrystal fabricated in this study.
さらに強いコントラストで $\mathrm{Y}$ 原子列が直接観察されて いる。これらの観察から明らかなように, 添加した Y 原子は粒界コア領域の原子面 1 層中に局在している。し かしながら，断面観察では界面上での Y 原子を 2 次元 投影像として観察するため, 真の原子構造を解明するこ とはきわめて困難である。

\section{2 平面 STEM 観察による界面ドーパント原子可視 化の理論解析}

界面上のドーパント原子 1 個 1 個の構造を明らかにす るためには, 界面と垂直な方向からの平面 STEM 観察 を組み合わせることが有効であると考えられる。しか し，上下のアルミナ結晶に埋まったわずか 1 原子層内の Y 原子からの信号を検出するためには, (1)結晶内部での 電子線の広がり, (2)厚い上下の結晶から $\mathrm{Y}$ 原子 1 個を 見分ける像感度, (3)実際の試料作製, などの大きなハー ドルが存在すると考えられる。そこで以下に計算機シミ ユレーションを用いることにより, 平面 STEM 観察の 可能性を検討した。

まず，埋まった界面上のドーパント原子を原子レベル で平面 STEM 観察するためには, 結晶内部に入射した 電子プローブの広がりを抑え, 原子分解能を保つことが 必須である。Fig. 3 に電子プローブの空間的な広がりを 計算機シミュレーションにより理論予測した結果を示 す。（a）は電子プローブを真空中でフォーカスした場 合，（b）は同一条件で $\sum 13$ 粒界の粒界面直上にフォー カスした場合のプローブの強度プロファイルを示す。な お, プローブの収束半角は $27.4 \mathrm{mrad,}$ 検出器角度範囲 は 81〜228 mrad，入射方位は粒界面と垂直な $\langle 5054\rangle$, $\Sigma 13$ 粒界のモデルは過去に第一原理計算により求めら れた O 終端の安定原子構造を用いた ${ }^{9)}$ 。Fig. 3 (a) (b) を比較すると, プローブの強度プロファイルは真空中に (a)

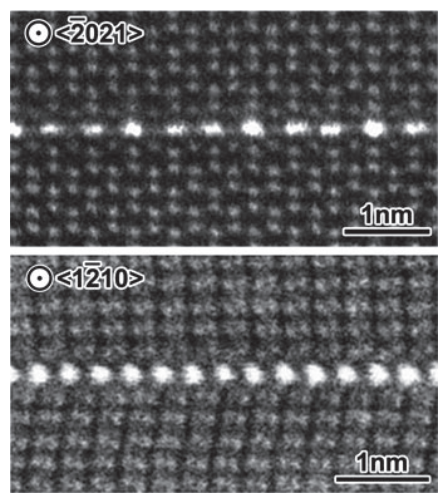

Fig. 2. HAADF STEM images of the $Y$ doped grain boundary observed from two orthogonal directions parallel to the interface plane. $\langle\overline{2} 021\rangle$ projection and $\langle 1 \overline{2} 10\rangle$ projection. 
フォーカスした場合と結晶内部にフォーカスした場合と ほぼ同等であることがわかった。つまり，この結晶方向 からの観察では埋もれた界面に電子線を絞り达んだ場合 でも十分に原子分解能を実現できることがわかった。

次に界面上に存在する 1 個の Y 原子からの信号を上 下の厚い結晶のバックグラウンドに対して検出可能かど うか検討するために，厚さの異なる三種類の試料に対し て, 先程の $\sum 13$ 粒界構造中の 1 個の $\mathrm{Al}$ 原子を $\mathrm{Y}$ 原子 で置き換えた構造を用いて HAADF STEM 像シミュレー

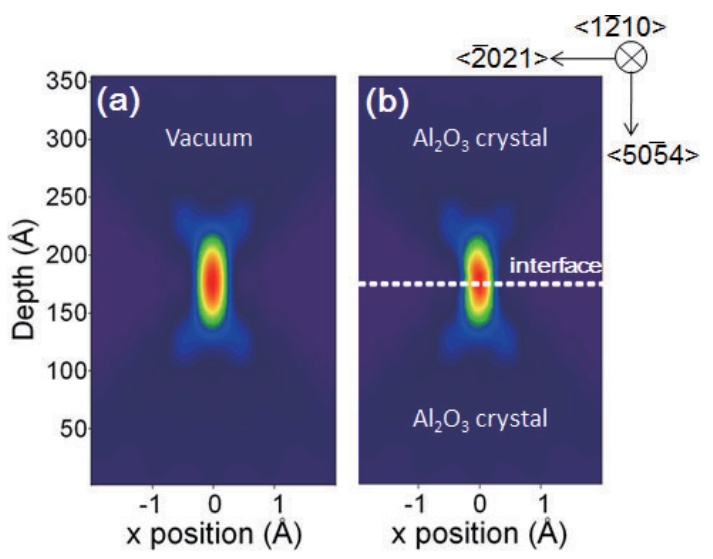

Fig. 3. (color online). Simulated intensity profiles of the focused electron beam in (a) complete vacuum and (b) focused on the interface plane between the top and bottom $\mathrm{Al}_{2} \mathrm{O}_{3}$ crystals, projected along the $\langle 1 \overline{2} 10\rangle$ direction.

(a)

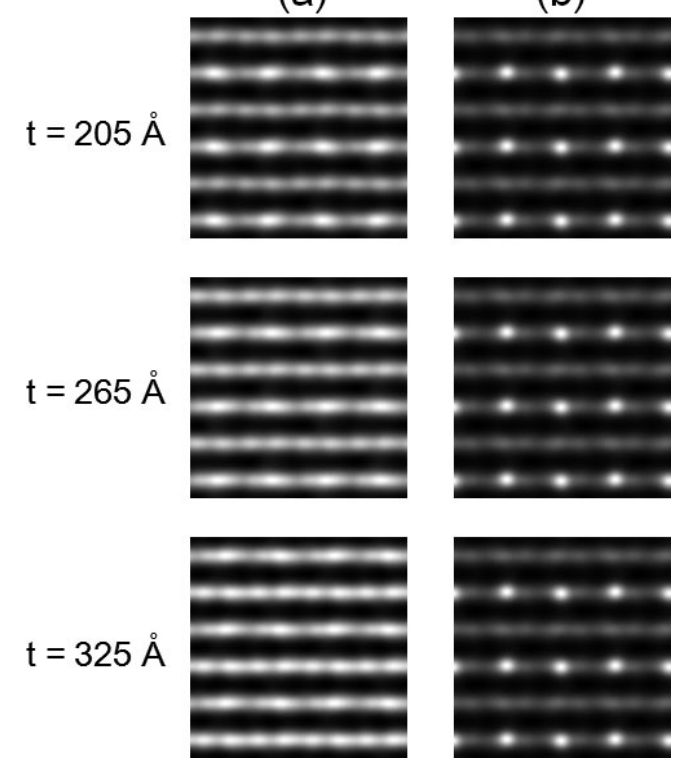

Fig. 4. Simulated HAADF STEM images of the Y doped $\Sigma 13$ grain boundary observed from the $\langle 50 \overline{5} 4\rangle$ direction. (a) Probe is focused on the sample surface. (b) Probe is focused at the interface.
ションを行った。その結果を Fig. 4 に示す。(a) は試料 の入射表面にプローブをフォーカスした場合，（b）は界 面直上にフォーカスした場合の計算結果である。 HAADF STEM 像中の横方向のストライプコントラスト は上下のアルミナ結晶中の $\mathrm{Al}$ 原子に起因するバックグ ラウンドである。（a）に示すように，試料表面に電子プ ローブをフォーカスした場合，試料が薄い場合にはわず かにYの信号がバックグラウンドに対して判別できる が，試料が厚い場合にはバックグラウンドにマスクさ れ，Yの信号は検出できないことがわかる。一方，(b) に示すように，界面直上に電子プローブをフォーカスで きれば，界面上の Y 原子を上下結晶のバックグラウン ドに対して明暸に観察できることがわかった。またこ れは試料が非常に厚い場合でも成り立つことがわかる。 以上の結果は, 粒界面と垂直方向である $\langle 50 \overline{5} 4\rangle$ から電子 線を入射し界面直上にプローブをフォーカスできれば, 原理的に界面直上の単一 $\mathrm{Y}$ 原子を直接観察できること を示唆している。

\section{3 アルミナ粒界上 $\mathrm{Y}$ 単原子の平面 STEM 観察}

上述の理論計算結果は, 界面上 $\mathrm{Y}$ 原子の直接観察の 可能性を示唆しているが，現実にはこのような観察に適 した平面 TEM 試料の作製が不可欠である。本研究で は，イオン研磨法を工夫することによって平面 TEM 試 料の作製に成功した。この試料を用いて HAADF STEM により原子レベルで粒界観察した結果を Fig. 5 に示す。 像中のストライプ状コントラストはシミュレーションで も予測された上下結晶中の $\mathrm{Al}$ 原子に起因するコントラ ストである。このバックグラウンドに加えて，ストライ プ状コントラスト中に明るい輝点が観察された。これが 界面上に存在する $\mathrm{Y}$ 原子 1 個 1 個に対応したコントラ ストであると考えられる。より詳細にこの像コントラス

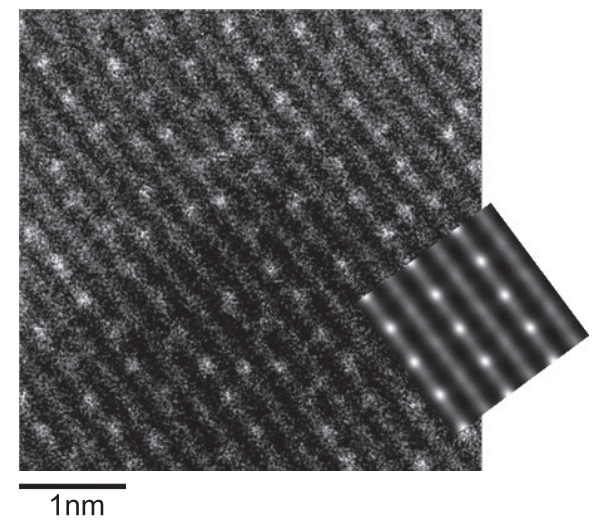

Fig. 5. Typical bright-field TEM image of the Y doped $\Sigma 13$ grain boundary observed from the $\langle 50 \overline{5} 4\rangle$ direction perpendicular to the interface plane. 


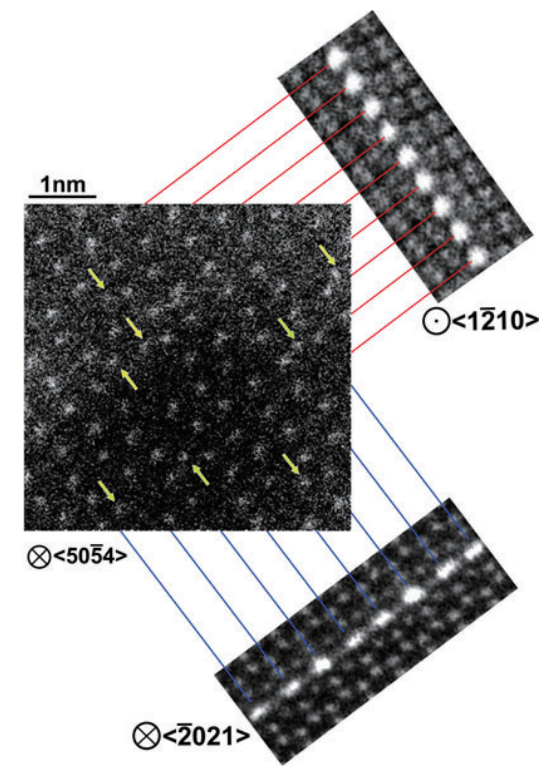

Fig. 6. (color online). Filtered plan-view HAADF STEM image highlighting the two-dimensional positioning of the interface $\mathrm{Y}$ atoms.

トを解析するために，ストライプ状コントラストを FFT フィルタリングにより取り除いた結果を Fig. 6 に示す。 平面 STEM 像と二つの垂直方向からの断面 STEM 像を 同時に示すが, 輝点の位置は断面 STEM 像でY 原子が 観察された位置と良く一致している。また，平面 STEM 観察により, $\mathrm{Y}$ 原子は界面上で 2 次元的な規則配列構造 を形成することが明らかとなった。これは整合性の高い $\Sigma 13$ 粒界の规則的な構造ユニットを反映していると考 えられる。しかし，矢印に示すように局所的には規則位 置からずれた Y 原子も存在しており, 界面上でドーパ ントは単に規則配列するだけではなく, 局所的に乱れた 配置も取りうることが初めて明らかとなった。このよう な局所的な原子構造の乱れを断面 STEM 観察で捉える ことはきわめて難しく, 本手法によりこれまで不可能だ ったより詳細な界面原子構造の同定が可能になるものと 期待できる。

\section{3. 金ナノ粒子/ $\mathrm{TiO}_{2}$ 界面の原子構造解析}

酸化物に担持された貴金属ナノ粒子は様々な化学反応 に良好な触媒活性を示す。中でも金微粒子の活性は，ナ ノ粒子のサイズと担体の種類に大きく依存してお $り^{10 \sim 14)}$, 金ナノ粒子と酸化物担体のナノ界面が触媒活 性発現の重要な要素であると考えられる。このようなナ ノ界面の重要性を背景に，これまで金ナノ粒子と酸化物 の界面形成に関する多くの研究報告がなされているが, この界面の原子構造を詳細に評価することは極めて難し

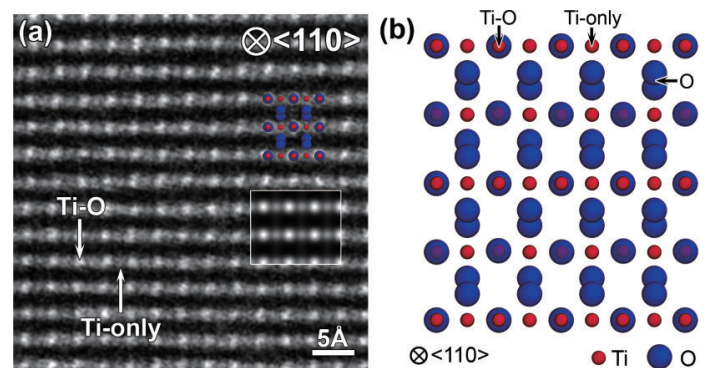

Fig. 7. (color online). (a) HAADF STEM image and (b) corresponding $\mathrm{TiO}_{2}$ atomic structure observed from $\langle 110\rangle$ direction.

く, 界面形成メカニズムに関して未だ本質的な理解が得 られていないのが現状である。そこで本節では, 収差補 正 STEM 法の優れた原子直視性および像コントラスト 特性を最大限利用することにより，酸化物上に担持した 金ナノ粒子の界面原子構造を直接評価することを目的と した。

3.1 金ナノ粒子/ $\mathrm{TiO}_{2}$ 界面の作製と平面 STEM 観察 本研究では, 金ナノ粒子/酸化物界面のモデル試料と して，金ナノ粒子 $/ \mathrm{TiO}_{2}$ 界面を作製した。 $\mathrm{TiO}_{2}$ は金ナノ 粒子の触媒活性を大きく向上させる担持材として知られ ている酸化物である。まず, 市販の $\mathrm{TiO}_{2}(110)$ 単結晶基 板（ルチル構造）をイオン研磨法により TEM 試料に加 エした。さらにこの TEM 試料を大気中で熱処理するこ とにより, イオン研磨による表面ダメージ層を除去し, 原子レベルで平坦な (110) 安定表面を形成した。この TEM 試料上に, 真空蒸着法により金ナノ粒子を蒸着し, 金ナノ粒子/ $\mathrm{TiO}_{2}(110)$ モデル界面を直接形成した。この ような試料に対して $\mathrm{TiO}_{2}$ の〈110〉方向から平面 STEM 観察を行った。Fig. 7 (a) に，ルチル型の $\mathrm{TiO}_{2}$ 結晶を 〈110〉方向から観察した HAADF STEM 像を示す。(b) にはルチル型 $\mathrm{TiO}_{2}$ 結晶を〈110〉方向から見た際の原子構 造モデルを示す。像中にはコントラストの異なる 2 種類 の輝点が水平方向に周期配列されているが, これらはい ずれも Ti 原子を含む原子カラムに対応している。像中 に STEM 像シミュレーション結果を示すが，より明る い原子カラムが $\mathrm{Ti}-\mathrm{O}$ からなる原子カラム（Ti-O カラ ム), 弱いコントラストが Ti だけからなる原子カラム (Ti-only カラム) に対応することがわかった。このよう に像コントラストから原子カラム種を区別できること は，金原子が結晶表面上でどの原子カラム上に吸着しや すいのかを判断する上で, 有益な情報になると考えられ る。Fig. 8 に $\mathrm{TiO}_{2}(110)$ 表面上に担持した金ナノ粒子の HAADF STEM 観察結果の一例を示す。 $\mathrm{TiO}_{2}$ 表面上の金 ナノ粒子は, 原子番号に依存した強いコントラストによ 


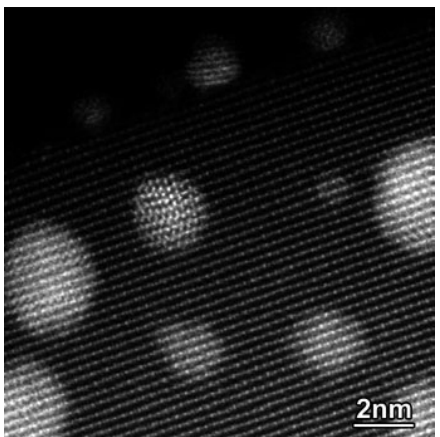

Fig. 8. A typical HAADF STEM image of Au nanoparticles deposited on $\mathrm{TiO}_{2}(110)$ surface.

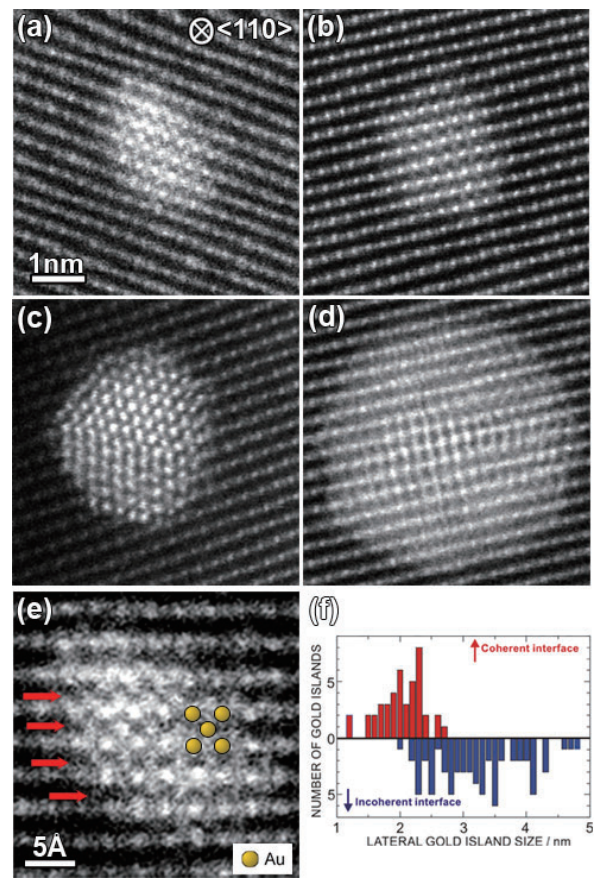

Fig. 9. (color online). Au size dependence on the interface structures between $\mathrm{Au}$ nanoparticles and $\mathrm{TiO}_{2}$ (110) surface. (a)-(d) HAADF STEM images of Au nanoparticles arranged in order of projected particle size. (e) Magnified image of the epitaxial Au structure shown in (a). (f) A histogram of the formation of coherent or incoherent interfaces.

り，その位置および形状を明膫に観察できることがわか った。また，より高倍で観察すれば，金内部の原子構造 までも直接観察することが可能である。この結果は，平 面 STEM 観察により，金ナノ粒子と $\mathrm{TiO}_{2}$ の原子構造を 同時に観察できることを示しており，金ナノ粒子と担体 との相対的な結晶方位を同定することを可能にする。

Fig. 9 に，典型的な金ナノ粒子の平面 STEM 観察結果 を示す1)。サイズ変化に伴う金の変化を調べるため, HAADF STEM 像を詳細に解析した結果, ユニークな特
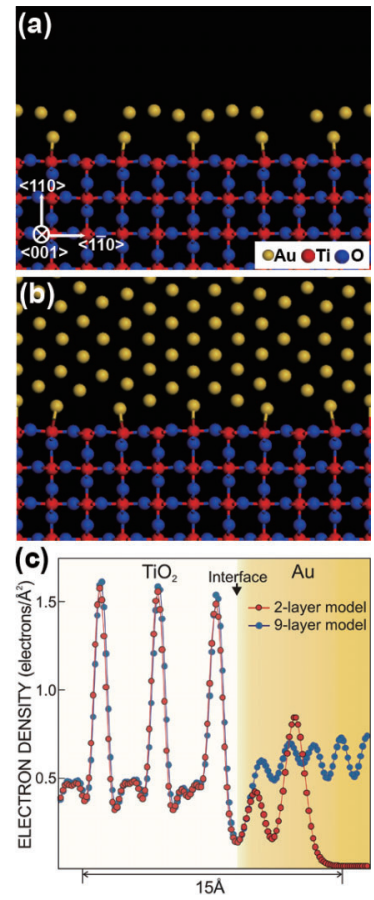

Fig. 10. (color online). Stable interface structures predicted by DFT calculations. (a) Two-atomic layer and (b) nineatomic layer $\mathrm{Au}$ on reduced $\mathrm{TiO}_{2}$ (110) surface. (c) The total electron density profiles projected onto atomic layers across the $\mathrm{Au}-\mathrm{TiO}_{2}$ interfaces.

徵があることが明らかとなった。金のサイズが $2 \mathrm{~nm}$ 以 下の場合（(a) および (b)), 金構造は $\mathrm{TiO}_{2}$ 表面の構造 に引きずられ，エピタキシャル的な構造を形成すること がわかった。つまり，この金微粒子と $\mathrm{TiO}_{2}$ の異相界面 はコヒーレント (整合) 的な界面構造を形成していると 考えられる。(e) に（a）の拡大像を示すが，このエピ タキシャル構造の特徵は, 金の 1 レイヤー目が Ti-O カ ラム上に存在し，2 レイヤー目が矢印で示すように，O カラム上に存在する点にある。すなわち金のエピタキシ ヤル構造は, 金原子が $\mathrm{TiO}_{2}$ 表面上の特定サイトと強い 相互作用を示すことに起因するものと考えられる。一 方，金ナノ粒子のサイズが $3 \mathrm{~nm}$ 以上になると，(c)-(d) に示すように，金ナノ粒子と $\mathrm{TiO}_{2}$ には明確な優先方位 関係は存在せず，その異相界面はインコヒーレント（非 整合）的な界面構造を形成していることがわかった。こ の場合, 金と $\mathrm{TiO}_{2}$ の格子ミスフィットは界面上で緩和 されるため, 金の原子構造はバルクの構造に近い構造を とることが予想される。（f）にコヒーレントな界面とイ ンコヒーレントな界面の形成頻度を金ナノ粒子のサイズ に対してプロットしたヒストグラムを示す。この図から 明らかなように, 金ナノ粒子と $\mathrm{TiO}_{2}(110)$ の界面構造は 2〜3 nm のサイズを境に大きく変化することがわかっ 
た。言い換えれば，金ナノ粒子の原子構造は 2 3 nm のサイズを境に界面構造変化と連動して大きく変化して いると考えられる。

\section{2 金ナノ粒子/ $\mathrm{TiO}_{2}$ ナノ界面の理論解析}

このような界面構造の金サイズ依存性を理論的に検証 するため, 第一原理計算を用いて金 $/ \mathrm{TiO}_{2}(110)$ 界面の安 定構造を理論予測した。その結果を Fig. 10 (a) (b) に 示す。この場合，金ナノ粒子のサイズ変化を考慮するた め, 初期構造として $\mathrm{TiO}_{2}(110)$ 上にバルクの格子定数を 有する金を（a）2 原子レイヤー堆積させたモデルと （b）9レイヤー堆積させたモデルを用いた。その初期構 造を第一原理計算により構造最適化した結果, 2レイヤ 一のモデルでは実験と同様に金原子は $\mathrm{TiO}_{2}$ 表面の特定 のサイトに強く吸着することで, エピタキシャル的な構 造に変化することが示された。この構造をもとに HAADF STEM 像シミュレーションを行った結果, 実験 像と良い一致を示した。一方，9レイヤーを堆積させた モデルの場合, 界面近傍の原子は多少緩和するものの, 厚い金レイヤーの拘束により大幅な構造緩和が許され ず, 全体としては初期構造と大きく変化しないインコヒ ーレント的な界面構造を保つことがわかった。つまり, 理論的にも金/ $\mathrm{TiO}_{2}$ (110)界面構造は金のサイズに大きく 依存することが示された。次に金の電子構造変化を調べ るため, 界面を横切る全電子密度をプロットした眓を Fig. 10 (c) に示す。9レイヤーの金の場合, 界面近傍 で若干の変化はあるもののすぐにバルクの金の電子密度 と同じになるのに対して, 2 レイヤーの金の場合, 電子 密度がバルクの金から大きく変化していることがわか る。この要因として, エピタキシャルな構造形成による 原子構造変化と $\mathrm{TiO}_{2}$ 側からの電荷輸送の両方の影響が 考えられる。本結果は, ナノサイズの金が $\mathrm{TiO}_{2}$ に担持 されることによりその原子・電子構造を大きく変化さ せ，通常のバルクの金とはまったく異なる性質を带びる 可能性を示唆している。

\section{4. ま と め}

収差補正技術の進展により, STEM 法は嘗てない分解 能と感度を獲得し, 物質・材料研究から有機・生物系ま で, 幅広くその応用範囲を拡大し続けている。STEM 法 の特徽である原子直視能力は様々な分野の研究に大きく 貢献しているが, STEM 法が 3 次元構造の 2 次元投影観 察である制約は未だ解決すべき課題として残っている。 最近では, STEMによる 3 次元観察法の開発に関する研 究が盛んに行われているが, 本研究で紹介した平面観察
は, 現状でも材料界面原子構造の 3 次元情報を抽出でき ることを示唆している。このように, STEM 法の特徵と 限界を良く理解した上で使いこなすことが，STEM のポ テンシャルを最大限引き出す上で重要であると考えられ る。

\section{謝辞}

本研究の遂行にあたり, Monash 大学の S.D. Findlay 博士, 名古屋大学の松永克志博士, 山本剛久博士, 東京 大学の溝口照康博士のご協力を頂きました。また本研究 の一部は, 科学技術振興機構戦略的創造研究推進事業個 人型研究さきがけ, 日本学術振興会科学研究費補助金若 手研究 $\mathrm{A}$ の支援により行われました。

\section{文献}

1) N. Shibata, S.D. Findlay, S. Azuma, T. Mizoguchi, T. Yamamoto and Y. Ikuhara: Nature Materials 8, 654 (2009).

2) N. Shibata, A. Goto, K. Matsunaga, T. Mizoguchi, T. Yamamoto and Y. Ikuhara : Phys. Rev. Lett. 102, 136015 (2009).

3) G. Hammerl, A. Schmehl, R.R. Schulz, B. Goetz, H. Bielefeldt, C.W. Schneider, H. Hilgenkamp and J. Mannhart : Nature 407, 162 (2000).

4) L. Sorba, B. Bratina, G. Ceccone, A. Antonini, J.F. Walker, M. Micovic and A. Franciosi : Phys. Rev. B 43, 2450 (1991).

5) N. Shibata, S.J. Pennycook, T.R. Gosnell, G.S. Painter, W.A. Shelton and P.F. Becher : Nature 428, 730 (2004).

6) J.P. Buban, K. Matsunaga, J. Chen, N. Shibata, W.Y. Ching, T. Yamamoto and Y. Ikuhara : Science 311, 212 (2006).

7) Y. Sato, J.P. Buban, T. Mizoguchi, N. Shibata, T. Yamamoto and Y. Ikuhara: Phys. Rev. Lett. 97, 106802 (2006).

8) S.D. Findlay, N. Shibata, S. Azuma and Y. Ikuhara : J. Electron Microscopy 59 (Supplement), S29 (2010).

9) K. Nakamura, T. Mizoguchi, N. Shibata, K. Matsunaga, T. Yamamoto and Y. Ikuhara : Phys. Rev. B 75, 184109 (2007).

10) M. Haruta, N. Yamada, T. Kobayashi and S. Iijima : J. Catal. 115, 301 (1989).

11) M. Valden, X. Lai and D.W. Goodman : Science 281, 1647 (1998).

12) T. Hayashi, K. Tanaka and M. Haruta : J. Catal. 178, 566 (1998)

13) F. Boccuzzi, A. Chiorino, M. Manzoli, D. Andreeva and T. Tabakova : J. Catal. 188, 176 (1999).

14) M. Haruta : Catal. Today 36, 153 (1997). 